\title{
The European Union and Developments in Crisis Management Operations and Peacekeeping
}

\author{
Ray Murphy*
}

\section{Introduction}

Thirty years ago, Henry Kissinger posed the question, "Whom do I call when I want to speak to Europe?” Now, the former U.S. Secretary of State is reported to have said: "I think one knows whom to call; I don't think Europe has yet decided how to give answers to all the questions."1 Europe's foreign policy is said to be fragmented and weak. A common defense and foreign policy still eludes the European Union (EU), and it is by no means clear that the deficiencies identified during the course of the crisis in the former Yugoslavia have been rectified. ${ }^{2}$ Part of the problem today may also be that there are now too many candidates willing to answer for Europe. Richard Holbrooke, the former U.S. Ambassador to the UN and also to NATO, recalled the Bosnian peace conference at Dayton, Ohio, in 1995, which had three co-chairmen, one of whom was Karl Bildt, the then EU special representative. ${ }^{3}$ But Germany, Britain, and France also sent envoys, and each indicated that Bildt did not speak for them.

Externally, the growing prominence of the European Union and its gradual assumption of some of the functions of the state had meant that its place in international relations has become more rather than less ambiguous over time. ${ }^{4}$ Many of the formal legal agreements between the EU and the outside world are so-called "mixed" arrangements. Furthermore, most of its informal foreign policy also operates within a somewhat unclear and evolving framework of cooperation and competition with the foreign relations of its member states. ${ }^{5}$ The overall situation has been complicated by the accession of new states to the EU.

Prior to the formation of the EU, European history was characterized by instability and armed conflict, and it was in the aftermath of one of Europe's bloodiest wars that a number of individual member states came together to lay the foundation for today's

* Dr. Ray Murphy is a Senior Lecturer in Law at the Irish Centre for Human Rights, National University of Ireland, Galway, Ireland. He lectures on peace support operations, international humanitarian law, and human rights.

1 Dan Bilefsky and Brian Knowlton, “U.S. Reaches out to a Europe that Has Yet to Emerge," International Herald Tribune (27 April 2007).

2 The EU is composed of two communities that each has a legal entity: the Atomic Energy Community (EURATOM) and the European Community, the latter being the more important of the two. See Duncan E. Alford, "European Union Legal Materials: A Guide for the Infrequent Users,” Law Library Journal 97:1 (2005): 49-76. The Lisbon Treaty formally creates a single legal personality for the EU and was scheduled for adoption in 2008. Ibid.

Neil Walker, “Europe at 50 - A Mid-life Crisis?”, Faculty of Law Annual Distinguished Lecture 2007 (Galway: National University of Ireland, 2007), 4.

Ibid. 
Union. At the heart of the European ideal was the aim of consolidating political and economic stability. It was thought that "tying countries together politically and economically [would be] ... a way to consolidate democracy and resolve traditional conflicts." 6 Those countries that were most affected by the human, economic, and political consequences of World War I and World War II recognized that their future well-being was dependent on economic and political stability.

The formal process of European integration began in 1951 with the establishment of the European Coal and Steel Community (ECSC). ${ }^{7}$ Although primarily economic in its focus, the ECSC was also aimed at facilitating political agreement between France and Germany. Six years later another treaty established the European Economic Community, which placed a greater emphasis on economic development but also sought to promote closer political union. Over the following forty-five years, an array of treaties covering many aspects of civil, social, economic, political, security, and defense issues have transformed this fledgling organization of six countries into one of twenty-seven states. ${ }^{8}$ In the early years of the EU, economic and social issues overshadowed agreements in the areas of defense and security. This changed after the EU's impotence was revealed when it was confronted with instability in the Balkans and the dissolution of the former Yugoslavia. A consequence of this was the placing of European security and military capabilities at the center of the EU agenda.

\section{Pillar Structures}

The framework and infrastructure of the EU is currently based on two treaties - the Treaty Establishing the European Community and the Treaty on European Union, which is supported by three pillars ${ }^{9}$ :

- First Pillar: the European Community (covering the policy areas encompassed by the EU). This contains the "old" European Community competencies, including areas such as the common market, agriculture, competition, and environment. It also includes EU trade policy with third countries, development, humanitarian assistance, and EU enlargement.

- Second Pillar: the Common Foreign and Security Policy (CFSP), including European Security and Defense Policy (ESDP). This succeeded the looser arrangement under what was known as European Political Cooperation.

- Third Pillar: police and judicial cooperation. This covers policing, asylum and immigration policy, and combating organized crime. It has little impact

6 Desmond Dinan, Ever Closer Union: An Introduction to European Integration, 3rd edition (New York: Palgrave Macmillan, 2005), 2.

7 France, Germany, Italy, Belgium, the Netherlands, and Luxembourg signed the European Coal and Steel Community Treaty in 1951.

8 Romania and Bulgaria became member states in 2007.

9 Dinan, Ever Closer Union, 5. The original Rome Treaty (1957), amended by the Single European Act (1986), Treaty on European Union (Maastricht Treaty 1991), Amsterdam Treaty (1997), and the Nice Treaty (2001). 
on CFSP. However, in the case of international police missions in places such as Kosovo and Bosnia, the EU can rely on existing cooperation procedures in this area. ${ }^{10}$

It is important at the outset to outline the role and function of the three main EU institutions: the European Council, representing the governments of the member states and headed by a rotating presidency; the European Commission; and the European Parliament. Each has different rights and competencies within each pillar. The first pillar is supranational in character, and is governed by well-established decision-making procedures. In many policy areas the Council decides by Qualified Majority Voting, and at times even by simple majority. The Commission, as the guardian of the treaties and main administrative body, makes proposals and implements decisions. The Second and Third Pillars are intergovernmental in nature, where the European Council acts as the sole legislator, usually on the basis of consensus. However, the Commission is allowed to table motions for political actions, and may be required to implement Council decisions. While civilian crisis management operations involve Pillar 1 (European Community) decision-making processes, EU military operations come under the umbrella of Pillar 2, thereby granting it an intergovernmental character. The Commission and European Parliament are informed of these decisions, but do not have legal power to influence the outcome.

It is noteworthy that the separation between the Second and Third Pillars means that the remit of the European Court of Justice is excluded from issues relating to CFSP policy. This ensures that there is no legal instrument that can oblige states to comply with CFSP provisions. In other words, there is still no legally enforceable binding obligation to act in concert that the European Court of Justice can enforce. ${ }^{11}$ It also raises the question of how much control (if any) the European Parliament, and by extension the citizens of the Union, exerts in the adoption of CFSP measures. It appears that neither the Parliament nor any citizen can challenge this assertion, as it cannot be tested before the Court. ${ }^{12}$ Its exclusion from the Third Pillar may have been a practical and prudent move, as it has been problematic enough to develop a credible crisis response policy without the additional background narrative of continuous legal challenges.

The challenges posed by the pillar structure makes some of the obstacles to providing coherent EU crisis management operations self-evident. Some key issues are the competence of the Commission and others on the Council (i.e., member states acting through the EU's Council structures). As external relations are deemed both intergov-

${ }^{10}$ Ulrich Schneckener, Developing and Applying EU Crisis Management: Test Case Macedonia, Working Paper No. 14 (European Centre for Minority Issues, December 2002), 4-5.

11 Trevor Salmon, "The European Security and Defence Policy: Built on Rocks or Sand?" European Foreign Affairs Review 10:3 (2005): 359.

12 Daniel Thym, "Beyond Parliament's Reach? The Role of the European Parliament in the CFSP,” European Foreign Affairs Review 11:1 (2006): 113; and Hans Born, et al., Parliamentary Oversight of ESDP Missions, Policy Paper No. 28 (Geneva: Geneva Centre for the Democratic Control of Armed Forces, 2008). 
ernmental and "community" activities, their management is split between the Commission and Council, with neither institution able to provide overall coordination and coherence. ${ }^{13}$ In this way, although the EU can employ a range of pre- and post-crisis management instruments and capabilities, providing a coherent or integrated response to a crisis can be problematic. ${ }^{14}$ The Constitutional Treaty for Europe would have nominally abolished the pillar structure and, according to its proponents, would have ushered in a new coherence to EU policies. ${ }^{15}$

\section{The EU's Capacities as a Global Actor}

By virtue of its economic size, population, range of policies, and political influence, the EU has become a leading global actor. Traditionally the EU has been a "civilian power" concerned with welfare generation and economic regulation. ${ }^{16}$ Unlike nationstates, it does not have a standing army, but rather has the ability to exert "soft power" by means of instruments such as economic support, trade concessions, regional developmental programs, and preferential loan arrangements through the European Investment Bank. Recent history has demonstrated that conflict prevention and peacekeeping tasks require the capability, capacity, and willingness to deploy military power when it becomes clear that economic and political methods are not achieving the desired results. The EU addresses this deficiency through the Second Pillar, a process that evolved very conservatively in the past but has acquired much more impetus in recent years, especially after the armed conflicts in the Balkans. A significant weakness exists in the EU institutional structures involved in crisis management operations. ${ }^{17} \mathrm{EU}$ military operations and the deployment of police and experts in the rule of law are institutionally and practically divorced from activities supported by the Commission in conflict prevention, crisis management, and post-crisis situations. The former operations come under Pillar 2, and are based on intergovernmental decisions within the context of ESDP.

13 International Crisis Group, EU Crisis Response Capability Revisited, Europe Report No. 160 (17 January 2005), 5.

14 Ibid., 404.

15 This was abandoned after the Constitutional Treaty was defeated in referenda conducted during 2005 in France and the Netherlands. The Treaty was designed to repeal and replace by a single text all the existing treaties (with the exception of the Euratom Treaty), and consolidate fifty years of European treaties. Following the difficulties in ratifying the treaty in France and the Netherlands, the heads of state and government decided, at the European Council meeting on 16 and 17 June 2005, to launch a "period of reflection" on the future of Europe. At the European Council meeting on 21 and 22 June 2007, European leaders reached a compromise and agreed to convene an IGC to finalize and adopt not a Constitution, but a "reform treaty" for the European Union (Lisbon Treaty).

16 Neil Winn, “CFSP, ESDP, and the Future of European Security: Whither NATO?” The Brown Journal of World Affairs 9:2 (2003): 149.

17 Catriona Gourlay, "European Union Procedures and Resources for Crisis Management," International Peacekeeping 11:3 (2004): 404-21. 
The controversy surrounding the war in Iraq revealed divisions in the relationship between some member states of the EU, and critics have been quick to declare that this is clear evidence that there can never be a common foreign and security policy among such a disparate group of nations. The import of these disagreements can be overstated, as they are a feature of all working democracies. The EU, through its Common Foreign and Security Policy (CFSP), recognizes the need to develop a defense and security policy with a military capability, limited in capacity but with sufficient strength to intervene in trouble spots, especially those that are close to home. ${ }^{18}$ A credible foreign policy must satisfy a few conditions: it must have strong and unequivocal political leadership, it must possess a robust operational military capacity, and it must possess the support of public opinion. ${ }^{19}$ The ability and determination to meet these three requirements is the most serious challenge that faces the EU in the development of a cohesive and resolute foreign and security policy; to date, progress has been inconsistent and slow. A lack of a united approach among political leaders-who continue to place their individual national interests above those of the EU as a whole-has not encouraged the citizens of the Union to become enthused or fully supportive of this project. Despite this political inertia and lack of engagement (except at times of crisis), the development of military capacities_-including plans to deploy Rapid Reaction Forces and battle groups backed by institutional arrangements-have made some significant advances. Indeed, the EU has successfully conducted a number of military, police, and rule-of-law missions to date.

At the time of writing, the EU is undertaking a wide range of civilian and military missions with tasks ranging from peacekeeping and monitoring implementation of a peace process to providing advice and assistance in military, police, border monitoring, and rule-of-law sectors. ${ }^{20}$ There is a perception that the EU lacks the capability to deploy and support strong and competent military forces. This belief underestimates the forces and resources that are available when taken in their totality. ${ }^{21}$ Nevertheless, the gap in military capacities between the U.S. and EU remains significant. ${ }^{22}$ A critical shortfall lies in the lack of strategic lift capacity, which impedes the EU's ability to rapidly deploy forces outside of the European continent. ${ }^{23}$ European governments are reluctant to increase expenditures on defense to make up this shortfall when compared

18 Dinan, Ever Closer Union, 560.

19 Winn, “CFSP, ESDP, and the Future of European Security," 151.

20 The Council of the EU, ESPD Newsletter, No. 6 (July 2008); details on ESDP at www.consilium.europa.eu/cms3_fo/showPage.asp?id=261\&lang=en.

21 Ståle Ulriksen, "Requirements for Future European Military Strategies and Force Structures,” International Peacekeeping 11:3 (2004): 457.

22 Salmon, “The European Security and Defence Policy: Built on Rocks or Sand?”, 373.

23 "Strategic lift" is a military term meaning the ability to transport troops and equipment over large distances. 
to their U.S. counterparts. ${ }^{24}$ An EU without a credible military element to ESDP, in support of the CFSP, lacks the full range of capabilities for an operational security and defense policy. ${ }^{25}$

This article addresses the developments involved in the construction of the Second Pillar and the creation of a framework for the European Security and Defense Policy (ESDP). It was natural that, in the aftermath of the break-up of the Soviet Union and the Warsaw Pact, the end of the Cold War, and the unification of Germany, the need to create formal EU defense arrangements would come into question. The EU continues to face a number of challenges associated with increased membership and globalization. One of these challenges is to provide a political union to complement its achievements in the economic sphere. The CFSP and its subset, the ESDP, represent the most tangible and visible aspects of this political ambition. ${ }^{26}$ The ESDP, however, remains dependent on the major powers within the EU, especially France, the United Kingdom, and to a lesser extent Germany. The article examines the tools available under the Second Pillar of the EU, including the publication of a European Security Strategy supported by an attendant institutional infrastructure, to the deployment of Rapid Reaction Forces for large-scale military operations, and the introduction of battle groups that can be moved to respond to crisis situations at very short notice. Recent and ongoing EU operations are also reviewed in this context. Representatives from the EU have often said that the EU and the UN are natural partners in multilateralism. ${ }^{27}$ This reflects the growing desire of the EU and its member states to establish the EU as a global actor. ${ }^{28}$ It is against this background that the EU and the UN have increased their cooperation in peacekeeping and crisis management operations.

\section{Evolution of the European Security and Defense Policy}

Early Developments in the Creation of a European Defense Policy

In 1969, EU leaders established a procedure known as European Political Cooperation

24 Stanley R. Sloan, NATO, The European Union, and The Atlantic Community, The Transatlantic Bargain Challenged, 2nd edition (New York, NY: Rowan \& Littlefield, 2005), 198.

25 Alistair J.K. Shepherd, “The European Union's Security and Defence Policy: A Policy without Substance?” European Security 12:1 (2003): 40.

26 Roland Dannreuther, ed., European Union Foreign and Security Policy, Towards a Neighbourhood Strategy. Setting the Framework (New York: Routledge, 2005), 2.

27 Jan Wouters, Frank Hoffmeister, and Tom Ruys, "Introduction," in The United Nations and the European Union: An Even Stronger Partnership (The Hague: TMC Asser Press, 2006), 1 .

28 This is especially evident from two key documents of 2003, the European Security Strategy (discussed below) and a Commission communication to the UN titled "The European Union and the United Nations - The Choice of Multilateralism,” COM (2003) 526 (10 September 2003.) 
whereby member states were called on to cooperate on foreign policy. ${ }^{29}$ Further developments took place in the following years, including meetings at the head of state and foreign minister levels, along with the establishment of institutional mechanisms, such as a Political Committee and working groups to follow up on summit meetings and deal with foreign policy issues as they arose. During this period a swift and secure communications system was set up between national foreign ministries and Brussels exclusively for the conduct of European Political Cooperation business. ${ }^{30}$ This may not appear at first glance to have been a remarkable event, but its significance is noteworthy for three reasons:

- It created a means of immediate direct communication to respond to emergencies

- It indicated a willingness by states to transmit information to one another regarding sensitive political issues

- It recognized the need for a secure communications system that was outside of military and security services control.

\section{Treaty of European Union $1991^{31}$}

There were a number of initiatives undertaken in the early 1980s to enhance European Political Cooperation and broaden its remit to encompass security and defense issues, but differences among member states meant that these efforts failed to yield any tangible results. ${ }^{32}$ A number of NATO and European Economic Community (the EU not yet having been established) states considered that defense issues should remain a NATO concern, and that no infringement on the security relationship with the U.S. could be considered.

The Treaty of European Union was significant, as it transformed the system of European Political Cooperation into the CFSP. This evolved to become the second intergovernmental pillar of the EU. The Treaty sets out its objective in the following terms: "to assert its identity on the international scene, in particular through the implementation of a common foreign and security policy including the eventual framing of a common defence policy, which might in time lead to a common defence.”33 The framers of the Treaty had the unenviable task of trying to reconcile the numerous and di-

29 Discussions on defense issues took place in tandem with those on the Coal and Steel Treaty leading to the signing of a European Defense Community (EDC) Treaty by all six founding member states in May 1952. Subsequently, differences relating mainly to fears arising from proposals to develop a political community (with the attendant implications of federalism) brought an end to the EDC, and by 1954 it was consigned to the status of a "stillborn sibling” of the nascent European community. Dinan, Ever Closer Union, 28.

Called “COREU,” for CORespondence EUropéene.

31 TEU (Maastricht Treaty), signed 7 February 1992, entered into force 1 November 1993. See Official Journal of the European Communities 191 (29 July 1992). Dinan, Ever Closer Union, 583.

33 TEU Treaty Title 1, Article B; available at http://europa.eu.int/en/record/mt/title1.html. 
vergent views of the member states. This is reflected in the constructive ambiguity of the language they adopted, which is aspirational and lacking in specificity and legal intent. The provisions establishing the CFSP are contained in a series of articles, the first of which sets out the objectives in a more comprehensive form ${ }^{34}$ :

- To safeguard the common values, fundamental interests, and independence of the Union

- To strengthen the security of the Union and its member states in all ways

- $\quad$ To preserve peace and strengthen international security, in accordance with the principles of the United Nations Charter as well as the principles of the Helsinki Act and the objectives of the Paris Charter ${ }^{35}$

- To develop and consolidate democracy and the rule of law, and respect for human rights and fundamental freedoms.

The reference to strengthening the security of the Union and that of the member states was sufficiently ambiguous to be acceptable to all states, including "neutrals" like Ireland, which were reluctant to embark on a policy that might have been seen to compromise its espoused policy of military neutrality.

\section{The Amsterdam Treaty of $1997^{36}$}

The Amsterdam Treaty introduced, among other things, a number of institutional and procedural changes to address weaknesses identified in the EU CFSP. The Treaty was concluded at a time when the crisis in the former Yugoslavia was still not resolved. Despite the deficiencies apparent in the EU's response to the crisis, issues pertaining to national sovereignty in the field of foreign policy proved a major stumbling block to achieving a coherent agreed structure and policy. The end result was a complicated system for decision making that required unanimity, but allowed for exceptions where qualified majority voting was acceptable as long as member states could declare that they were not bound by such a decision. Dinan's comment that "these reformed decision making procedures were more complicated than the original ones without necessarily being an improvement on them" aptly summarized the changes made to CFSP procedures. ${ }^{37}$

34 Ibid., Title V, Article J.1.

35 The Conference on Security and Cooperation in Europe (CSCE) was established by the Final Helsinki Act in 1975. In 1994, it was renamed the Organization for Security and Cooperation in Europe (OSCE). The Paris Charter was adopted by a meeting of member states of the CSCE in 1990.

36 Agreed by EU leaders on 17 June 1997 and signed on 2 October 1997. Entered into force on 1 May 1999. See Official Journal of the European Communities 340 (10 November 1997).

37 Dinan, Ever Closer Union, 594. 
The Amsterdam Treaty reiterated, with some very minor adjustments, the objectives set out in the Treaty on European Union, but reinforced these by outlining three key instruments for their implementation ${ }^{38}$ :

- Principles and general guidelines as defined by the European Council

- Common strategies as decided by the European Council, to include duration of joint actions and the means and resources to be made available

- Joint actions and common positions as recommended by the Council. ${ }^{39}$

Member states also agreed to the creation of the position of a High Representative for CFSP, who would also be the Secretary-General for the Council. ${ }^{40}$ This is an important appointment made by the EU Council, and as such largely evades parliamentary scrutiny. ${ }^{41}$ This helped address the recurring problem of who was authorized to speak on behalf of the EU.

\section{Crisis in Yugoslavia and the Launch of the European Security and Defense Policy (ESDP)}

The EU relied on economic power and financial sanctions in its attempts to bring a halt to hostilities in the former Yugoslavia in the 1990s. ${ }^{42}$ The EU did not have the capacity to respond militarily, and for this reason it was forced to acknowledge that its efforts to implement a negotiated settlement lacked credibility. Individual EU countries did supply troops to the largely ineffective United Nations Protection Force (UNPROFOR) mission, but there was no coordinated response from the Union. In fact, the response from the EU was characterized by a unilateralist approach from member states rather than the multilateralism on which the Union was supposedly based. ${ }^{43}$ The deployment of the NATO-led Implementation Force (IFOR) and later Stabilization Force (SFOR) missions that replaced UNPROFOR again included EU countries, but the composition of these two forces was dominated by the United States. The lack of any military capability demonstrated the apparent impotence of the EU to resolve crises in its own backyard, not to mention the wider world, and served to reinforce its dependence on NATO and the transatlantic link. Chris Patten, the former EU Commissioner for External Relations, summarized Europe's shameful response to the crisis as follows:

38 Amsterdam Treaty, Title V, Articles J.3, J.4, J.5, and J.6; available at http://europa.eu.int/eurlex/lex/en/treaties/dat/11997D/htm/1199D.html.

Ibid., Article J.4.1.

Ibid., Article J.8.3. Mr. Javier Solana, a former minister in the Spanish government and Secretary-General of NATO and the WEU, was appointed as the first what is commonly referred to as the HRSG in 1999; his tenure was extended for a second five-year term in 2004.

Thym, "Beyond Parliament's Reach? The Role of the European Parliament in the CFSP," 118.

Adrian Treacher, "From Civilian Power to Military Actor: The EU’s Resistible Transformation,” European Foreign Affairs Review 9 (2004): 56.

Ibid., 56. 
The people of Western Balkans are our fellow Europeans. We cannot wash our hands of them. Let us remember the consequences of our refusal to get involved. The shattered ruins of Vukovar. The ghastly siege of Sarajevo. The charnel house of Srebrenica. The smoking villages of Kosovo. The European Union did not commit these crimes. But 200,000 or more fellow Europeans died in Bosnia and Herzegovina alone. As Europeans we cannot avoid a heavy share of responsibility for what happened. ${ }^{44}$

The conflicts in the Balkans showed that the CFSP could only be credible if it was backed up by the capacity to employ military power. ${ }^{45}$ The European Council meeting in Cologne in 1999 addressed this deficiency by launching the ESDP, thereby giving the EU access to military structures and forces, although their deployment was limited in scope to the so-called "Petersberg Tasks" ${ }^{\text {"6 }}$ - i.e., humanitarian and rescue missions; peacekeeping efforts; and tasks of combat forces in crisis management, including peacemaking. ${ }^{47}$

\section{The North Atlantic Treaty Organization (NATO) and the Western European Union (WEU)}

Brussels and Washington Treaties. In the aftermath of World War II, tensions continued to exist between Germany and its former adversaries, some of whom remained concerned about the possibility of renewed conflict. The United Kingdom and other countries that had been subject to German aggression wished to retain a more formal alliance structure. They also had to address the new threat from a Soviet Union that occupied much of Eastern Europe, including East Germany. Germany-the country with the largest population in Europe and with commensurate industrial and military capacities-would have to be integrated into any new European security arrangements. The Western European Union (WEU) was created by the Brussels Treaty on Eco-

${ }^{44}$ Christopher Patten, "The Western Balkans: The Road to Europe," speech to the European Affairs Committee in Berlin (28 April 2004); available at www.ear.eu.int/agency/main/ agency-a1a2g3.htm.

45 Burkard Schmitt, "European Capabilities: How Many Divisions?” in EU Security and Defence Policy: The First Five Years (1999-2004) (Paris: EU Institute for Security Studies, 2004), 89.

46 The tasks refer to those agreed in the 1995 Declaration of the Western European Union at Petersberg, Germany, which were incorporated into Title V of the Treaty of European Union.

47 The CFSP was revised in some important respects in the Amsterdam Treaty (1997) and the later Treaty of Nice (2003). The main features of CFSP are outlined in Article 17.1 and 17.2 of the Treaty on European Union and read in the amended version as follows:

1. The common foreign and security policy shall include all questions relating to the security of the Union, including the progressive framing of a common defense policy, which might lead to a common defense, should the European Council so decide. ...

2. Questions referred to in this Article shall include humanitarian and rescue tasks, peacekeeping tasks and tasks of combat forces in crisis management, including peacemaking. 
nomic, Social, and Cultural Collaboration and Collective Self-Defense in $1948 .^{48}$ The driving force behind this was the U.S. reluctance to become involved in European security at that time. The main feature of the Treaty was the commitment to mutual defense in the event of an armed attack on any of the member states. This demonstration of the determination and cooperation among signatory states to work together facilitated talks with the U.S. and Canada that led to the Washington Treaty of 1949 and the establishment of NATO. The following year, WEU members decided to merge their military organization into NATO, thereby recognizing its pre-eminent role in preserving the security of Europe and the North Atlantic littoral. ${ }^{49}$

The collapse of the Warsaw Pact in 1990 meant that NATO was left without its primary purpose-protecting Western Europe from Communist aggression from the East—and it had the option of either seeking new tasks or facing possible dissolution. The confluence of the ending of the Cold War and the outbreak of armed conflict in Yugoslavia offered a timely opportunity for NATO to reinvent itself as a guarantor of stability in Europe. Within the EU itself, the debate on how to address security and defense issues centered on two opposing points of view. The so-called "Atlanticists," led by the United Kingdom, opposed the development of an EU military capability. They preferred to retain the predominance of NATO, with its guarantee of collective defense, and believed that the EU was incapable of providing the military capacity to match this provision. The "Europeanists," on the other hand, favored providing the EU with a distinct military arm, but in the early stages their proposals lacked clarity and realism. The "Atlanticist" view prevailed and, at the NATO Council meeting in Berlin in June 1996, it was agreed to allow the WEU to use the Combined Joint Task Forces (CJTF) mechanism that had been developed by NATO in military situations that would not involve the U.S. ${ }^{50}$

Saint Malo Declaration. A dramatic change of policy occurred in 1998, when the British and French governments declared that "the Union must have some capacity for autonomous action, backed up by credible military forces, the means to decide to use them and a readiness to do so, in order to respond to international crisis." ${ }^{\text {" }}$ In a surprising development, the EU had been given the tools to become an effective military actor. The momentum created at Saint Malo meant that movement towards a real-

48 Signed in March 1948 by Belgium, France, Luxembourg, the Netherlands, and the United Kingdom, as amended by the Protocol signed in Paris in 1954. A history of the WEU is available at www.weu.int/History.htm.

49 The difficulty of integrating the Federal Republic of Germany into the emerging security structures was resolved by allowing both Italy and Germany to join the Brussels Treaty in September 1954. These arrangements were formalized by the Paris Protocols of 1954 that created the WEU as a new international organization.

50 A Combined Joint Task Force mission is one in which resources are shared in accordance with the needs of a particular task and composed of those countries willing to participate.

51 Joint statement by the French and British Governments, Franco-British Summit, Saint Malo, France, 4 December 1998. 
istic security policy was inexorable. ${ }^{52}$ However, the focus at Saint Malo was on the provision of military capabilities, rather than on providing rationales for their use, as the latter had already been set forth in the Petersberg Tasks. ${ }^{53}$ A route had been opened to allow the CFSP to develop a path to the creation of a credible ESDP supported by appropriate military instruments and resources. The reluctance of the U.S. to commit ground forces in the war in Kosovo served to reinforce the necessity for the EU to have the capacity to respond to such a crisis in accordance with the principles set out in the Saint Malo Declaration.

At the Cologne European Council meeting in June 1999, the member states agreed that the EU should be given the means and capabilities to carry out its tasks with regard to security and defense matters. ${ }^{54}$ However, the extent of the ESDP was limited to the undertaking only of the Petersberg Tasks - a restriction that seemed to confirm the dominance of the "Atlantacists," who were determined that NATO should remain the cornerstone of the collective defense of its members. Subsequently, the WEU was wound up in June 2001 and its responsibilities were transferred to the EU. ${ }^{55}$

Helsinki Headline Goal (1999) and the Creation of New Bodies to Coordinate the ESDP (2000). The fallout from the crisis in Kosovo precipitated consequences within both the UN and the EU. A further significant development occurred at the European Council meeting in Helsinki in December 1999, when it was decided that the EU should be able to act autonomously in situations where NATO as a whole was not prepared to do so. The EU should be given the tools and capabilities to undertake military operations in response to international crisis situations. With respect to this force's military capabilities, the Council declared that:

A common European headline goal will be adopted for readily deployable military capabilities and collective capability goals in the fields of command and control, intelligence and strategic transport will be developed rapidly, to be achieved through voluntary coordinated national and multi-national efforts, for carrying out the full range of Petersberg Tasks. ${ }^{56}$

52 Winn, “CFSP, ESDP, and the Future of European Security," 158.

53 Andrea Ellner, “The European Security Strategy: Multilateral Security with Teeth?” Defence and Security Analysis 21 (2005): 226.

54 Schmitt, “European Capabilities: How Many Divisions?”, 90.

55 The Treaty of Nice (2003) transferred the main institutions and competences of the WEU to the EU, and made the ESDP the military instrument of the CFSP. Richard Youngs, "The European Security and Defence Policy: What Impact on the EU's Approach to Security Challenges?” European Security 11:2 (2002): 101.

56 Presidency Progress Report to the Helsinki European Council on Strengthening the Common European Policy on Security and Defence, Annex I to IV; available at http://europa.eu.int/council/off/conclu/dec99/dec/99_en.htm. 
This led to the establishment of the Helsinki Headline Goal (HHG), where the member states set objectives for military capabilities in accordance with the Petersberg Tasks for the period 1999 to $2003 .^{57}$

The Headline Goals have been characterized as "essentially a plan for acquiring military capability for power projection." ${ }^{58}$ The EU was not proposing to establish its own standing army. Lacking any form of institutional military organization, the EU requested member states to indicate the numbers and types of forces they were prepared to commit. These were then listed in what has become known as the Helsinki Force Catalogue, which sets out the contributions available from the various countries. However, this catalogue did not guarantee that member states would provide the forces listed, as they could take into account their availability and operational readiness at the time of any request. ${ }^{59}$

In order to coordinate these ESDP efforts, three new bodies were established in $2000 .^{60}$ The most important of these was the Political and Security Committee, which monitors the international situation, exercises political control, and provides strategic direction to crisis management operations. It is a key strategic actor and central preparatory body, made up of national representatives at the ambassadorial level permanently based in Brussels. It has been described as an unusually cohesive committee with a club-like atmosphere, a high level of personal trust, and driven by a common commitment to pioneer cooperation. ${ }^{61}$ The EU Military Committee consists of military chiefs from member states, and is responsible for giving military advice, developing an overall concept of crisis management operations, and conducting military relations. There is also an EU Military Staff, which provides early warning and strategic planning with respect to the Petersberg Tasks and implements the decisions of the Military Committee. The EU recognized that the fulfillment of the Petersberg Tasks required civil crisis management capabilities, and four priority areas were identified in 2000: ci-

${ }^{57}$ Ibid. The Goal was defined as follows: "Member states have set themselves the headline goal: by the year 2003, cooperating together voluntarily, they will be able to deploy rapidly and then sustain forces capable of the full range of Petersberg Tasks ... in operations up to Corps level (up to 15 brigades or 50,000 to 60,000 persons). These forces should be militarily self-sustaining ... for at least one year."

58 Giovanna Bono, “The EU’s Military Doctrine: An Assessment,” International Peacekeeping 11:3 (2004): 444.

59 Gerrard Quille, "Implementing the Defence Aspects of the European Security Strategy: The Headline Goal 2010," European Security Review 23 (2004): 5; available at www.isiseurope.org.

60 Provisionally established by Council Decisions of 14 February 2000, Official Journal, L49/1 (22 February 2000); permanently established by Council Decisions of 22 January 2001, Official Journal, L-27/1 (30 January 2001).

61 See Christoph O. Meyer, The Quest for a European Strategic Culture: Changing Norms on Security and Defense in the European Union (New York, NY: Palgrave Macmillan 2007); and Tom Ruys, Background Paper on EU Crisis Management Operations, Working Paper No. 108 (Leuven: Institute of International Law, Katholieke Universiteit Leuven, May 2007). 
vilian policing, rule of law, strengthening civil administrations, and ensuring protection of civilian populations. ${ }^{62}$

Berlin Plus Arrangements (2002). Both the EU and NATO recognized the need for closer coordination to avoid duplication in the use of resources and capabilities. Achieving agreement in this area was delayed by Turkey, owing to fears that the ESDP could be used against Turkish interests. ${ }^{63}$ After prolonged discussions it was agreed in December 2002 that the EU would be assured of access to NATO military assets and operational planning capabilities for the conduct of EU-led military operations. ${ }^{64}$ The four main elements of the so-called "Berlin Plus" arrangements are:

- Assured access to NATO planning resources

- Presumption of the availability of pre-identified NATO common assets and capabilities

- European command options, including the role of the NATO Deputy Supreme Allied Commander Allied Forces Europe (DSACEUR)

- A NATO-EU security information agreement, allowing for the exchange of classified information between the two organizations. ${ }^{65}$

While the Berlin Plus arrangements did strengthen the Union's arsenal of crisis management tools, success depended on the relationship between the U.S. and the EU (and particularly on the role of the United Kingdom in blringing the two together). ${ }^{66}$

Despite such developments, the results were tempered by a number of shortfalls. Although these have been acknowledged, it is difficult to determine what goals have actually been achieved. ${ }^{67}$ Most member states' military expenditures are traditionally spent on personnel and infrastructure, rather than on new equipment or research. This may well be a good thing for the EU as a whole, but the practical consequences of such spending patterns for the conduct of military operations at the strategic and operational level should not be underestimated. The establishment of the battle groups (discussed below) and the European Defense Agency were intended to remedy this. The delays in

62 See Jan Wouters and Tom Ruys, “UN-EU Cooperation in Crisis Management,” in The United Nations and the European Union: An Even Stronger Partnership, ed. Jan Wouters, Frank Hoffmeister, and Tom Ruys (The Hague: TMC Asser Press, 2006), 229-65; quoted at 235.

63 See generally Özlem Terzi, “New Capabilities, Old Relationships: Emergent ESDP and EUTurkish Relations,” Southeast European Polities 3 (2002): 43.

64 Catriona Gourlay, "European Union Procedures and Resources for Crisis Management," International Peacekeeping 11:3 (2004): 410.

65 Idem. The agreement was formally concluded by an exchange of letters on 17 March 2003; two weeks later, the EU launched its first ESDP military mission, Operation Concordia, in the Former Yugoslav Republic of Macedonia.

66 Catriona Mace, “Operation Concordia: Developing a 'European' Approach to Crisis Management,” International Peacekeeping 11:3 (2004): 47.

67 Wouters and Ruys, "UN-EU Cooperation in Crisis Management,” 237. 
launching the EU-led force for Chad in 2007-08 called into question the success of these arrangements.

\section{The European Security Strategy}

\section{New Doctrines and Strategy}

While the early period of the ESDP's life was reactive and event-driven, it was only a matter of time before the need arose for a strategic policy in relation to EU capacity and capabilities. ${ }^{68}$ In 2003, the European Council formally adopted A Secure Europe in a Better World as the European Security Strategy (ESS), and in so doing took on the mantra of "effective multilateralism." "69 The UN and EU also concluded a Joint Declaration on EU-UN cooperation in crisis management, covering civilian and military operations. ${ }^{70}$ Although the ESS document essentially codified existing practice, it is critical to understanding the circumstances in which EU forces can be deployed, and is considered to be "the sorely missed common political platform needed to develop the EU military strategy, doctrine, and force structure concepts." ${ }^{, 71}$ It was the first major attempt to provide a guiding framework for the EU's international role in the security arena. It outlines the multilateral approach adopted by the EU to international crises and its determination to abide by principles embodied in international law and the UN Charter. ${ }^{72}$

The European Security Strategy reflected an important statement of support for the UN in the post-9/11 climate, at a time that can only be described as a low point for the CFSP. ${ }^{73}$ It is also clear from the ESS that the EU, and not the UN, must set the agenda. Europe must meet contemporary challenges through the application of the full spectrum of instruments for crisis management and conflict prevention at its disposal, in-

${ }^{68}$ For helpful background on the European Security Strategy, see A Secure Europe in a Better World - European Security Strategy (ESS) (Brussels: European Council, 12 December 2003); available at www.consilium.europa.eu/uedocs/cms.Upload/78367.pdf.

Jan Wouters, The United Nations and the European Union: Partners in Multilateralism, Working Paper No. 1 (Leuven: Leuven Centre for Global Governance Studies, May 2007), 2. Joint Declaration on UN-EU Cooperation in Crisis Management, New York, 24 September 2003. This led to the establishment of the EU-UN Crisis Management Steering Committee. Ulriksen, "Requirements for Future European Military Strategies and Force Structures," 458. The document declares that the EU is committed to upholding and developing international law and the UN Charter: "The fundamental framework for international relations is the United Nations Charter. The United Nations Security Council has the primary responsibility for the maintenance of international peace and security. Strengthening the United Nations, equipping it to fulfill its responsibilities and to act effectively is a European priority.” European Security Strategy, 9.

73 Sven Biscop and Edith Drieskens, "The European Security Strategy: Confirming the Choice for Collective and Comprehensive Security," in The United Nations and the European Union: An Even Stronger Partnership, ed. Jan Wouters, Frank Hoffmeister, and Tom Ruys (The Hague: TMC Asser Press, 2006), 267. 
cluding political, diplomatic, military and civilian, trade, and development activities. ${ }^{74}$ This is a more comprehensive approach to addressing security concerns based on principles of preventive strategy that goes significantly beyond the traditional "military threat assessment."75 In this it differs from the National Security Strategy of the United States, which is unilateralist in approach and emphasizes the right of the U.S. to act unilaterally, under the concept of pre-emptive action. ${ }^{76}$ The United States' approach to the UN is reflected in the manner in which it is placed together with a number of other organizations and given a rather lukewarm expression of U.S. "commitment to lasting institutions like the United Nations, the World Trade Organization, the Organization of American States and NATO as well as other long-standing alliances."

A comparison between the European Security Strategy and the U.S. National Security Strategy highlights the strategic divergence between them. ${ }^{78}$ Although the U.S. strategy devotes more space to democracy, human rights, and trade, these are placed within the overall framework of the "Global War on Terror." It puts great emphasis on the use of military instruments, including acting pre-emptively, before threats are fully formed. The European Security Strategy, on the other hand, advocates a holistic approach that seeks to integrate all instruments into a structural policy of prevention and stabilization, operating through partnership and rule-based multilateralism. It is also consistent with the approach outlined in the UN's Report on the High Level Panel on Threats, Challenges and Change, and the UN Secretary-General's report titled In Larger Freedom. ${ }^{79}$

Despite these differences in approach with the U.S. (which were exacerbated in the case of several member states by the war in Iraq), the European Security Strategy stresses the continued importance of the transatlantic link. ${ }^{80}$ It does, however, make it clear that the EU sees this relationship as requiring balance and effectiveness. In this regard, the EU must increase its capabilities and coherence so as to be able to act

74 It identifies the five key threats to European security: terrorism, proliferation of weapons of mass destruction, regional conflicts, state failure, and organized crime. European Security Strategy, 5-6, and 11.

75 Gerrard Quille, “The European Security Strategy: A Framework for EU Security Interests,” International Peacekeeping 11:3 (2004): 424.

76 U.S. National Security Strategy (USNSS), launched by President George W. Bush in September 2002; available at www.whitehose.gov/nsc/nss.pdf. See Quille, "The European Security Strategy: A Framework for EU Security Interests,” 423.

77 USNSS, 5.

78 Sven Biscop, “For a 'More Active' EU in the Middle East,” Egmont Paper No. 13 (Brussels: Royal Institute of International Relations, 2007), 21.

79 United Nations, A More Secure World: Our Shared Responsibility. Report of the High-level Panel on Threats, Challenges and Change, UN Doc. A/59/565, 2 December 2004; Secretary-General of the United Nations, In Larger Freedom: Towards Development, Security and Human Rights for All, UN Doc. A/59/2005 (21 March 2005). It was also supported by the heads of state and government at the 2005 World Summit Outcome, GA Res. A/RES/60/1 (24 October 2005).

80 European Security Strategy, 13. 
autonomously. The impetus to draft the European Security Strategy had its origins in the aftermath of the Balkan conflict, when EU accession became the carrot to be offered to aspirant countries that proved themselves to be peaceful and capable of abiding by democratic principles. This policy was shown to be effective with EU candidate states, but it is less clear what leverage it provided with those states that were not seeking membership. ${ }^{81}$ It also offered a framework for future approaches to regional and global security. ${ }^{82}$ The decision to push forward with a sense of urgency in formulating an EU security strategy may have originated in the U.S. decision to go to war in Iraq, rather than growing out of a considered debate on the need for a firmer policy platform. ${ }^{83}$ Not only did the Iraq crisis place the U.S. at odds with a number of its European NATO allies, but there was also a serious lack of unanimity regarding the war among EU member states. In this way, the European Security Strategy was driven not by calls for reform within the EU, but by outside influence in the shape of U.S. unilateral action. ${ }^{84}$ It has been argued that differences over Iraq were the most critical feature in bringing about acceptance of the European Security Strategy by the member states. Indeed, as one scholar has written, "without the lessons of Iraq and the resultant necessity to respond to shifts in the U.S. international behavior and strategic outlook, the first European strategy document might well not have been adopted." 85

\section{Building a Secure Neighborhood}

The European Security Strategy addresses the critical issue of security outside of Europe by means of a policy described as "Building Security in our Neighborhood," which emphasizes the importance of having "well-governed” countries within Europe's neighborhood, including the Middle East. ${ }^{86}$ Enlargement has been the main foreign policy instrument used by the EU to guarantee the stabilization of its eastern flank by bringing about significant economic opportunities for new member states. However, nationalist movements in states formerly under the control of the USSR still pose a threat to European peace and security. The issue of independence for Kosovo, which is vigorously opposed by nationalist elements within Serbia, has the potential to destabilize the region. ${ }^{87}$

81 Asle Toje, “The 2003 European Union Security Strategy: A Critical Appraisal,” European Foreign Affairs Review 10:1 (2005): 129.

82

83

84

85

86

87

Ellner, “The European Security Strategy: Multilateral Security with Teeth?”, 223.

Toje, “The 2003 European Union Security Strategy: A Critical Appraisal,” 117.

Ibid., 120.

Jirí Šedivý, One Year On: Lessons from Iraq, Chaillot Paper No. 68 (Paris: Institute for Security Studies, March 2004), 107.

Ulriksen, "Requirements for Future European Military Strategies and Force Structures,” 461. See Executive Summary and Recommendations in International Crisis Group, "Kosovo: No Good Alternatives to the Ahtisaari Plan,” Europe Report No. 182 (14 May 2007); International Crisis Group Media Brief, “Serbia’s New Government: Turning from Europe,” Belgrade/Brussels (31 May 2007); and Megan Harris, “Kosovo’s Uncertain Outlook,” United Press International (11 June 2007). 
"Enlargement fatigue" is slowing the process of application and accession for those states that wish to join the Union, and it has yet to be seen how the European Security Strategy will help consolidate and focus the security gains from enlargement (stability and integration) and provide the momentum to extend that security to neighboring states. ${ }^{88}$ The strategy acknowledges that large-scale aggression against any EU member state is now unlikely. Instead there are new threats that are more diverse and difficult to predict, including global terrorism (which is now linked to religious extremism), proliferation of weapons of mass destruction, regional conflicts, state failure (bad governance), and organized crime. The strategy acknowledges that the EU "needs to develop a strategic culture that fosters early, rapid and when necessary, robust intervention," but any EU military operation should only be carried out in accordance with CFSP objectives, which are based on the aspirations of the Union in world affairs as set out in the strategy document. ${ }^{89}$ The basis for consultations with major partners on strategic issues throughout the world is based on the principles set out in the strategy document.

One of the greatest challenges facing the EU-one that is not addressed in the security strategy —is the formidable challenge of formulating a security policy that involves twenty-seven member states. ${ }^{90}$ Overall, the European Security Strategy has to be seen as a crucial part of the ongoing development of CFSP/ESDP and efforts to address shortfalls in capabilities across the full range of the Petersberg Tasks. The EU has moved from the phase of theory to that of practice. The effectiveness of the strategy will be determined not by its text, but by the results of the actions that are undertaken in its name. ${ }^{91}$

\section{Rapid Reaction Forces}

The Helsinki Headline Goal envisaged an autonomous EU force of 50,000 to 60,000 troops, deployable within sixty days of the decision to launch an action and sustainable for at least one year. This was to be known as a Rapid Reaction Force and was declared operational at the EU summit in Thessaloniki in 2003, even though it was only two-thirds ready at the time. ${ }^{92}$ New Helsinki Headline Goals were identified for 2010

88 Quille, “The European Security Strategy: A Framework for EU Security Interests,” 427. Petersberg: Missions for the EU Military Forces," in EU Security and Defence Policy: The First Five Years (1999-2004), ed. Nicole Gnesotto (Paris: EU Institute for Security Studies, 2004), 82.

90 Toje, “The 2003 European Union Security Strategy: A Critical Appraisal,” 123.

91 Javier Solana, The European Strategy - The Next Step, Chaillot Paper No. 75 (Paris: Institute for Security Studies, 2004), 18; originally delivered as an address to the Finnish Institute of International Affairs, 25 February 2004.

92 Ellner, “The European Security Strategy: Multilateral Security with Teeth?”, 230. 
with a view to having available forces capable of carrying out military operations in a manner that at some stage will not require the presence of American troops. ${ }^{93}$

\section{EU Battle Groups}

At the Military Capabilities Commitment Conference in 2004, the gathered EU defense ministers committed to the "further improvement of military capabilities and offered contributions to the formation of EU Battle Groups (as part of Rapid Response Elements), in the context of implementation of the European Security Strategy."94 By February 2005, the member states made commitments to the formation of thirteen battle groups with full operational capability from 2007 onwards. ${ }^{95}$ This provides the EU with the capacity to undertake two concurrent battle group-size rapid response operations. ${ }^{96}$

In military terms, a battle group can be described as the minimum militarily effective, credible, rapidly deployable, coherent force capable of stand-alone operations, or for deployment in the initial phase of larger operations. It is based on a combined arms battalion size force of approximately 1500 soldiers, with combat support and combat service support elements. ${ }^{97}$ The model adopted by the EU is based on the principle of multi-nationality, and can be formed by a single member state or by a Framework nation with support from other nations or a multinational coalition of member states. ${ }^{98}$ The key objectives for the EU in regard to the battle groups are:

93 Under the Helsinki Headline Goals for 2010, the member states' force contributions should be deployable together, become more interoperable in theater, and sustainable with regard to material and logistics. Jean-Paul Perruche, "The Way Ahead," Impetus: The Bulletin of the EU Military Staff (Spring /Summer 2006): 4. ESDP Presidency Report, EU Security and Defence, Core documents 2004, Chaillot Paper No. 75, vol. 5 (Paris: Institute for Security Studies, February 2005), 350.

95

96

Idem. Just four countries with large standing armies (France, Italy, Spain, and the United Kingdom), declared that they possess the capacity to provide all of the elements of a single battle group. Other member states agreed to participate in the battle groups in conjunction with others, and to provide niche capabilities. Such capabilities could include contributions of medical groups (Cyprus), water purification units (Lithuania), sea-lift coordination groups (Greece), and structure of a multinational and deployable Force Headquarters (France). Ireland does not have the capacity to provide a battle group as a single deployable element, but it can offer an armored personnel carrier-mounted light infantry company and niche capabilities for such matters as explosive ordnance disposal, combat engineers, transport supply support, and administrative and logistics expertise at the operational HQ level. Speech by the Irish Minister for Defense, Institute of Foreign Affairs Conference on EU Battle Groups, University of Limerick, 28 April 2006; available at www.iiea.com.

EU Council Secretariat Factsheet, EU Battle Groups, November 2005; available at "Combat support" is support and operational assistance provided to combat elements, while "service support" is support provided to combat forces, mainly in the area of administration and logistics. www/consilium/eu.int/ue.eu.int/Newsroom. 
- To make the decision to launch an operation within 5 days of the Council's approval of the general political and military parameters of the operation.

- To have forces on the ground no later than 10 days after the decision to launch that are sustainable for 30 days initially, and up to a maximum of 120 days.

- To be able to undertake two simultaneous missions in response to a crisis situation or an urgent request by the UN Security Council. ${ }^{99}$

The commitment to deploy two battle groups simultaneously means that the "tasking” for possible operations can be rotated among the thirteen such groups that were guaranteed by the defense ministers. Some countries indicated their willingness to provide a complete battle group, while others are part of coalitions that can be deployed within the Framework concept. Thus, the requirement to make high-readiness troops immediately available will be shared among all willing participants. An obstacle that could put pressure on achieving the target deployment times is that the process of making a decision to launch not only requires Council approval, but also the agreement of the member states contributing troops to the mission in question. It is conceivable that national decision-making processes could be affected by domestic political pressures that may not be easy to overcome. Some member states may not be in a position to take part in a specific mission, or could participate only under conditions that do not contravene national policies (e.g., a UN mandate). Battle groups differ from the Rapid Reaction Force concept in terms of scale, lead-in time, and length of deployment. Their size means that they are not capable of major military action, but they can form part of a broader strategy as an "early entry" or enabling force to prepare for the deployment of a larger, more robust force. A task that appears very suitable for battle groups in the context of the mutually reinforcing civilian and military approach favored by the EU would be providing a rapid response to humanitarian crisis operations at short notice. The delays in deploying the EU force to Chad in late 2007 and early 2008 demonstrate that there are some serious operational issues to be worked out before the EU battle group concept can be considered effective.

\section{ESDP Becomes Operational}

\section{Police Mission in Bosnia and Herzegovina}

The ESDP became truly operational in 2003, and did so in a way that few policy makers could have anticipated. ${ }^{100}$ Four distinct operations were undertaken that year: two

99 The timelines envisaged for such a rapid deployment mean that battle groups must be maintained at a state of readiness of five to ten days' notice to move. EU Factsheet, The EU Battle Groups and the EU Civilian and Military Cell, February 2005; available at www.consilium.europa.eu/uedocs/cmsUpload/Battlegroups.pdf.

100 Gustav Lindstrom, “On the Ground: ESDP Operations,” in EU Security and Defence Policies: The First Five Years (1999-2004), ed. Nicole Gnesotto (Paris: EU Institute for Security Studies, 2004), 111. 
police missions and two military missions, one of which was conducted outside Europe. The EU had already committed itself to one such operation in March 2002 when it had guaranteed that it would deploy an EU Police Mission in Bosnia-Herzegovina $(\mathrm{BiH})$ on 1 January 2003, to replace the UN International Police Task Force deployed pursuant to the General Framework for Peace (Dayton Agreement) in December 1995. ${ }^{101}$ The EU Police Mission was the first civilian crisis management operation to be initiated under the ESDP. This was the first instance of UN-EU cooperation on the ground during an actual crisis management operation, and was a test of the ability to ensure a "seamless transition" from one organization to the other. ${ }^{102}$ While the operation was launched before the completion of the drafting of the European Security Strategy, the mission is directly relevant to two of the five key threats identified in the document: state failure and organized crime. ${ }^{103}$ For the first three years of its existence, the EU Police Mission was involved in developing police independence and accountability, fighting organized crime and corruption, ensuring the financial viability and sustainability of local police forces, and creating institutions supported by capacity building. ${ }^{104}$ At no stage did it have either an executive mandate or the authority to carry out any operational tasks. In January 2006, the EU was requested by BiH to establish a follow-on mission for a period of two years with a modified mandate and size. ${ }^{105}$ The EU Police Mission is currently focused on supporting the police reform process and developing local capacity and regional cooperation in the fight against organized crime by establishing a sustainable, professional, and multiethnic police service in accordance with best European and international standards. ${ }^{106}$

\section{Operation Concordia in the Former Yugoslav Republic of Macedonia}

In March 2003, the EU launched its first military mission, Operation Concordia, at the invitation of the government of the Former Yugoslav Republic of Macedonia (FYROM). This force replaced NATO troops that had been operating there since August 2001, and was primarily tasked with overseeing the implementation of the Ohrid

${ }^{101}$ Annex 11 requested the UN to establish a UN International Police Task Force (IPTF) to carry out various tasks including monitoring, observing, and inspecting law enforcement activities, training and advising law enforcement personnel, and advising the government of $\mathrm{BiH}$.

102 Thierry Tardy, EU-UN Cooperation in Peacekeeping: A Promising Relationship in a Constrained Environment, Chaillot Paper No. 78 (Paris: Institute for Security Studies, June 2005), 55.

${ }^{103}$ Kari M. Osland, “The EU Police Mission in Bosnia and Herzegovina,” International Peacekeeping 11:3 (2004): 544.

${ }^{104}$ Lindstrom, “On the Ground: ESDP Operations,” 113-14.

${ }^{105}$ EU Council Joint Action 2006/49/CFSP, 30 January 2006.

${ }^{106}$ EU Factsheet, EU Police Mission in Bosnia and Herzegovina (EUPM), March 2006. The force was reduced from a total of approximately 560 personnel to 198 international members (170 police and 20 civilians), supported by some $200 \mathrm{BiH}$ nationals. 
Framework Agreement. ${ }^{107}$ This agreement brought an end to fighting between the Macedonian authorities and ethnic Albanians that threatened to plunge the country into civil war. ${ }^{108}$ The force consisted of approximately 400 lightly-armed troops drawn from twenty-six states, including all member countries of the EU, with the exception of Denmark and Ireland.

Denmark decided to opt out of any commitments to the CFSP/ESDP process at the time of the Treaty of European Union, and did not play any role in Operation Concordia. ${ }^{109}$ Ireland, with its light infantry-based forces and experience in UN peacekeeping missions, was ideally suited to participate in this operation. It represented an ideal opportunity to give a positive indication of Ireland's preparedness to take part in the first EU military operation and demonstrate its willingness to shoulder its share of the EU security burden. Operation Concordia, however, did not have a UN mandate, and in these circumstances Ireland could not participate. The force was deployed in patrolling the ethnic Albanian populated areas along Macedonia's borders with Serbia, Kosovo, and Albania.

In addition to being the first EU military mission, Operation Concordia was also the first occasion in which NATO assets were made available to the EU Force under the Berlin Plus arrangements. ${ }^{110}$ The operation headquarters was located at Supreme Headquarters Allied Powers (SHAPE) in Belgium, with regional headquarters in the FYROM capital Skopje, along with the cities of Kumanovo and Tetovo, which were all areas of potential unrest. Operational command was vested in the NATO Deputy Supreme Allied Commander in Europe, and field command was exercised by an officer of two-star general rank approved by both NATO and the EU. All three worked in close coordination with the EU Special Representative based in FYROM. ${ }^{111}$ The force remained under the political control and strategic direction of the EU, but close links were maintained with NATO at all levels. ${ }^{112}$ Coordination between the EU and NATO was achieved by the "double-hatting" of key personnel at the co-located headquarters for the mission. Regular contact was maintained throughout the operation between the

107 The Ohrid Framework Agreement was signed on 13 August 2001 between the Macedonian and Albanian political parties to the fighting, under the auspices of the U.S. and EU. It was named after Lake Ohrid, where negotiations took place.

108 Mace, “Operation Concordia: Developing a 'European’ Approach to Crisis Management,” 475.

${ }^{109}$ Amendments to the Treaty on European Union subsequently embodied in the Amsterdam Treaty by means of a special protocol stipulate that Denmark does not participate in the preparation and implementation of any actions with defense implications. Amsterdam Treaty, Protocol on the Position of Denmark, Part 11, Article 6, Exemptions from Articles J3 (1) and J7.

${ }^{110}$ Mace, “Operation Concordia: Developing a 'European’ Approach to Crisis Management,” 474.

${ }^{111}$ Lindstrom, “On the Ground: ESDP Operations,” 118.

112 Mace, “Operation Concordia: Developing a 'European’ Approach to Crisis Management,” 482. 
Political and Security Committee of the EU and the North Atlantic Council of NATO. ${ }^{113}$

Operation Concordia was terminated on 15 December 2003, as the presence of a military force was no longer considered necessary. However, as the situation had not fully stabilized, the EU force was immediately replaced by an EU police mission, Operation Proxima. ${ }^{114}$ In terms of peacekeeping, Concordia was a relatively small operation, but it was multi-national in composition, and demonstrated that the EU was capable of conducting small-scale military crisis management operations in support of ESDP objectives. In addition, it showed that the Berlin Plus arrangements for EU access to NATO assets could function well at the operational level. ${ }^{115}$ This was evidenced by the fact that the same blueprint was used for the much larger EU operation in Bosnia the following year. The EU's response to the situation in Macedonia was a key element in preventing further ethnic conflict that would have had implications for neighboring countries, including Greece.

\section{EU Missions in the Democratic Republic of Congo}

Operation Artemis. In early 2003, there was a significant increase in the number of deaths and internally displaced persons arising from the ten year long conflict in the Democratic Republic of the Congo (DRC). The withdrawal of Ugandan forces from the UN peacekeeping force (MONUC) led to a deteriorating security situation in the Ituri region. ${ }^{116}$ The UN Secretary-General was concerned about the possibility of a large-scale massacre of civilians by undisciplined militias, and made an urgent request to the EU to provide a force to stem the tide of violence in the DRC until a larger and more robust UN force could be deployed. The memories of Srebrenica and Rwanda were still very fresh in the minds of the international community, and a descent into

${ }^{113}$ The Political and Security Committee consists of national representatives at the ambassadorial level with responsibility for the political control and strategic direction of crisis management operations. The North Atlantic Council has effective political authority and powers of decision and consists of permanent representatives of all NATO member countries. See Chapter 7 of NATO Handbook, "Policy and Decision Making” (Brussels: NATO Office of Information and Press, 2001; updated 2004).

114 Operation Proxima was established by a Council Joint Action, 2003/681/CFSP, on 29 September 2003. The new operation was a police mission that was expected to last for one year. Approximately $200 \mathrm{EU}$ police officers were mandated to help fight organized crime, monitor border police operations, and to introduce EU police standards along the lines envisaged for the EU Police Mission. As this was not a military mission, there was no requirement to make use of NATO capabilities under the Berlin Plus arrangement. The original mandate was extended by an additional year, and the mission ended on 14 December 2005.

${ }^{115}$ Mace, “Operation Concordia: Developing a 'European’ Approach to Crisis Management,” 487.

${ }^{116}$ Annual Review of Global Peacekeeping Operations 2007 (Boulder, CO: Lynne Rienner, 2007), 58-65; and www.un.org/Depts/dpko/missions/monuc/. 
wholesale slaughter would have been a further blow to the credibility of the UN, especially the Security Council. ${ }^{117}$

The EU responded positively, and the Security Council approved a resolution mandating the presence of an EU-led force. ${ }^{118}$ The mandate authorized "the deployment of an Interim Emergency Multinational Force in Bunia in close coordination with MONUC.” The force was deployed to protect the airport and the camps for internally displaced persons in Bunia and, if necessary, protect the civilian population as well as other humanitarian personnel in the town. ${ }^{119}$ The launching of the operation (codenamed "Artemis") was an important step in the progressive development of the ESDP, and provided a test case for the guiding principles in preparation for the drawing up of the European Security Strategy. This marked a significant development in EU military operations: it was the first operation conducted independent of NATO; it was initiated by the EU; and it was conducted outside of Europe pursuant to Chapter VII of the UN Charter. ${ }^{120}$

The EU force, consisting of approximately 2000 troops (of whom 1700 were French ${ }^{121}$ ) began operations on 6 June 2003. ${ }^{122}$ Because of the balance of forces in this instance, the NATO capabilities available under the Berlin Plus arrangements were not called upon, and the operation was led and commanded by the French acting as a Framework nation. ${ }^{123}$ Issues such as command and control, logistical support, and sustainability remained under national control, thus avoiding the requirement to enter into any complex multi-national arrangements. As with Operation Concordia, close coordination was maintained between the military commanders and the EU Special Representative working in the region. Operation Artemis was a relatively small military operation with a narrow mandate and a predetermined duration. Nevertheless, it demonstrated that the EU could establish relevant organizational structures and successfully conduct an operation in support of the stabilization and reconstruction process. ${ }^{124} \mathrm{It}$ also introduced the "bridging model," which is aimed at deploying a force with the intention of giving the UN time to mount a new operation in cases where the UN is not able to respond to an urgent request for rapid deployment in a crisis situation. ${ }^{125}$ In

117 Ståle Ulriksen, Catriona Gourlay, and Catriona Mace, “Operation Artemis: The Shape of Things to Come?” International Peacekeeping 11:3 (2004): 513.

${ }^{118}$ UNSCR 1484 passed on 30 May 2003.

${ }^{119}$ Ulriksen, Gourlay, and Mace, “Operation Artemis: The Shape of Things to Come?”, 513.

${ }^{120}$ Ibid., 508.

${ }^{121}$ Lindstrom, “On the Ground: ESDP Operations,” 119.

122 Ibid., 119. See also United Nations Peacekeeping in the Service of Peace, Operation Artemis - The Lessons Learned in the Interim Emergency Multinational Force (United Nations, Peacekeeping Best Practices Unit, Military Division), 3; available at http://pbpu.unlb.org/ pbpu/library/artemis.pdf.

${ }^{123}$ A Framework nation (FN) is a member state that has volunteered to take specific responsibilities in an operation over which the EU exercises political control.

${ }^{124}$ Ellner, “The European Security Strategy: Multilateral Security with Teeth?”, 231.

125 Ibid., 232. 
September 2003, responsibility for the security of the region was handed back to the MONUC.

Operation Artemis was criticized as essentially a French operation commanded by French officers. In fact, eight other states contributed forces: Belgium, Brazil, United Kingdom, Canada, Germany, Greece, South Africa, and Sweden. ${ }^{126}$ In addition, Austria, Hungary, Ireland, Italy, the Netherlands, Portugal, and Spain contributed officers to HQ operations. ${ }^{127}$ In this instance the "framework nation" principle worked effectively, but there were considerable political misgivings, particularly in Africa, because of France's historic legacy as a colonial power in the region. ${ }^{128}$ It is noteworthy that no EU states took part in the strengthened UN force that took over from the Operation Artemis force, despite requests from the UN Secretariat for some assets to be "re-hatted." "29 This may indicate that EU states are willing to support UN-mandated operations when they are led by regional organizations such as the EU itself or NATO, but not in cases where a traditional UN force led by a multinational headquarters under direct control of the Department of Peacekeeping Operations is deployed.

EUFOR. On 25 April 2006, the UN Security Council adopted Resolution 1671, authorizing the EU to deploy a standby force (EUFOR) to the DRC for the four months following the first round of presidential and parliamentary elections. ${ }^{130}$ This force consisted of about 2000 mainly French and German troops, operating under a Chapter VII mandate. Their primary function was to assist MONUC in providing security and protecting civilians. Most of the troops were deployed as "over the horizon" stand-by forces in Gabon, but around 800 secured the airport at Kinshasa, and another 400 were deployed in August 2006 to suppress fighting between rival political factions. Although the mission did not make a significant military difference, it did have an important political impact. ${ }^{131}$

\section{The EU and Bosnia and Herzegovina}

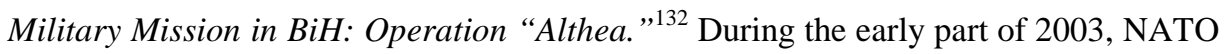
began a critical analysis of its commitment to the Stabilization Force (SFOR) in Bos-

${ }^{126}$ Ulriksen, Gourlay, and Mace, “Operation Artemis: The Shape of Things to Come?”, 520.

${ }^{127}$ Ibid., 520.

128 Ibid., 521.

${ }^{129}$ Tardy, EU-UN Cooperation in Peacekeeping: A Promising Relationship in a Constrained Environment, 57.

${ }^{130}$ Annual Review of Global Peacekeeping Operations 2007, 59; and www.un.org/Depts/dpko/ missions/monuc/.

${ }^{131}$ In April 2005, the EU established its first civil mission for crisis management in Africa within the framework of the ESDP. Its mandate is to advise the Congolese Integrated Police Unit in adhering to international policing standards.

132 Javier Solana, European Union High Representative for CFSP, "Launch of the EU 'ALTHEA' Operation in Bosnia and Herzegovina, Sarajevo,” S0337/04, December 2004. The Council of the EU decided on 12 July 2004 (Council Joint Action 2004/570/CFSP of 12 July 2004) to conduct a military operation in BiH within the framework of the ESDP. 
nia. ${ }^{133}$ At the same time, in the wake of two successful EU missions in the DRC and Macedonia, international pressure was being exerted on the EU to consider taking over responsibility from NATO in Bosnia and Herzegovina. This was agreed to at the European Council meeting of 12 December 2003, where it was announced that an ESDP mission, including a military component, would be established in $\mathrm{BiH}$ if and when NATO decided to terminate SFOR. This new force, to be known as EUFOR, possessed the same legal authority as SFOR to implement the terms of the Dayton Agreement. ${ }^{134}$

Acting under Chapter VII of the UN Charter, the mission had two fundamental objectives. First, it would guarantee the secure environment required for the core objectives of the Office of the High Representative's Mission to $\mathrm{BiH}$ in regard to the Implementation Plan and the Stabilization and Association Agreement, and would contribute directly to it. ${ }^{135}$ Second, this force would have a particular focus against organized crime.

The Office of the High Representative was also to act as the EU Special Representative and be given responsibility for coordinating the activities of all the different EU agencies in $\mathrm{BiH}$, including the EU Police Mission, EUFOR, and the EU Monitoring Mission (EUMM). ${ }^{136}$ Javier Solana signaled that he wanted the EU Special Representative to act as the primus inter pares among the heads of all these agencies, and the Council mandated him to promote overall EU political coordination and chair a coordinating group composed of all EU actors in the field, including the EUFOR commander, with a view to ensuring that the implementation aspects of the EU's action plan were in concert. ${ }^{137}$ This ensured that the mission would have a political focus along with the application of military power. It was clear that there were serious concerns within the EU about the mission, and an awareness that Operation Althea would

${ }^{133}$ This force had succeeded the NATO-led Implementation Force (IFOR) deployed pursuant to the General Framework Agreement for Peace, more commonly referred to as the Dayton Agreement, concluded in Dayton, Ohio, on 21 November 1995, and signed in Paris on 14 December 1995.

134 Javier Solana, EU Statement on the Summary of the Report by EUHR for CFSP on a Possible EU deployment in BiH, 1 March 2004.

${ }^{135}$ Under Annex 10 of the Dayton Agreement, a High Representative was appointed by the UN to monitor the implementation of the settlement. The Implementation Plan set out the core tasks for the Office of the High Representative. The SAA is designed as the principal instrument of the Stabilization and Association Process (SAP) to structure a signatory state's progress towards EU membership. SAP was launched in 1999 to provide a new framework for the EU's relations with countries in the Western Balkans, including Albania, Bosnia, Croatia, Macedonia, and Serbia and Montenegro. SAP offers countries in the region a "membership perspective" that explicitly recognizes that the future of the region lies with the EU. SAP is designed to encourage regional cohesion.

136 The EUMM was established in 2001 and succeeded the European Community Monitoring Mission (ECMM), which was set up in 1991. The mission was deemed successfully completed on 31 December 2007. See Javier Solana, "EU High Representative for CFSP Welcomes the Successful Completion of the EUMM,” S375/07, Brussels, 27 December 2007.

${ }^{137}$ Ellner, “The European Security Strategy: Multilateral Security with Teeth?”, 233. 
present a greater challenge than did Operation Concordia in Macedonia. There was also some trepidation regarding the fact that this mission would represent the first real operational test of the Berlin Plus arrangements. ${ }^{138}$ Solana pointed out that, in order to be effective, a force would need to have good intelligence, flexible and integrated capabilities, and be able to call on "over the horizon" reserves. The EU did not have the means at that time (notwithstanding the development of the battle group concept) to increase its capabilities in these three areas, either singly or collectively, without external support-support that in this case could only come from NATO. In this way, Solana left the door open for a continuing NATO presence and involvement in $\mathrm{BiH}$.

Comprehensive Policy for BiH. Under the European Security Strategy, the European Council adopted a Comprehensive Policy for BiH in June 2004 that stated that all EU actors/instruments - whether political, military, police-related, or economicwould contribute to implementing this overall EU policy. ${ }^{139}$ In order to ensure close cooperation and coherence between these actors/instruments, a number of key arrangements were put in place. The most important of these in regard to the deployment of EUFOR were the modalities for close liaison with the NATO Operational Headquarters at Supreme Headquarters Allied Powers Europe (SHAPE) at Mons in Belgium, the EU Command Element at NATO Joint Forces Command (South), and the Force Headquarters in Sarajevo. In accordance with the Berlin Plus arrangements implemented in Operation Concordia, the EU Operation Commander would also be the NATO Deputy Allied Supreme Commander, with his headquarters for the EUFOR mission co-located with his NATO headquarters in Mons, Belgium. EUFOR would take over all the existing facilities, infrastructure, and locations from SFOR and operate under the same Status of Forces Agreement.

The objective of this ESDP mission was to set $\mathrm{BiH}$ irreversibly on the track towards EU membership. ${ }^{140}$ The implication was that $\mathrm{BiH}$ would have to respond positively to EU initiatives across the full range of activities in both political and security areas. In the long term, the EU wanted a stable, viable, peaceful, and multiethnic $\mathrm{BiH}$, cooperating peacefully with its neighbors and firmly on the track toward becoming a full member of the European community. In the medium term, the EU would support BiH's own efforts to move toward EU integration by contributing to a safe and secure environment. Finally, in the short term, the EU would ensure a seamless transition from SFOR to EUFOR in order to help maintain a secure environment for the implementation of the military aspects of the Dayton Agreement. ${ }^{141}$ These were the commitments that the EU was prepared to make to maintain peace in $\mathrm{BiH}$, while simultaneously setting out targets that must be achieved by the country itself.

138 Sloan, NATO, The European Union, and The Atlantic Community, 201.

139 “European Security Strategy, Bosnia and Herzegovina-Comprehensive Policy," adopted by the European Council, 17-18 June 2004; available at www.eusrbih.org/policy/?=1,1,1.

140 Javier Solana's remarks at the Istanbul NATO Summit, issued by the EU Council, Ref CL04130EN, 28 June 2004.

${ }^{141}$ Press Release, "EU Military Operation in Bosnia and Herzegovina,” ATH/02, 1 October 2004; available at http://ue.eu.int/Newsroom. 
The Council of the EU adopted a Joint Action on 12 July 2004, and announced its readiness to launch an ESDP mission in $\mathrm{BiH}^{142}$ UN Security Council Resolution 1575 (2004) authorized EUFOR as the legal successor to SFOR and welcomed the decision of NATO to conclude the SFOR operation and to maintain a presence in $\mathrm{BiH}$ in order to continue to assist in the implementation of the Dayton Agreement. ${ }^{143}$ The EU Political and Security Committee would exercise political control and provide strategic direction to EUFOR, and was authorized on the recommendation of the EU Operation Commander and the EU Military Committee to allow the participation of other states in the mission that fell into the following categories: non-EU European NATO members and Canada (if they so wished); countries that are candidates for EU accession; and potential partners or other third states that may be invited. The formal change of command between the two forces took place on 2 December 2004.

\section{EU Mission to Chad/Central African Republic}

The EU-led mission to Chad in 2008 marked a departure from the previous pattern of cautious, safe policy decisions with respect to EU military deployments. ${ }^{144}$ During 2006, in the Political and Security Committee, the option of launching an ESDP mission in southern Lebanon was given serious consideration. The argument went, why not assume command when EU states were contributing the bulk of the forces anyway? In the event, only a UN operation proved acceptable to the parties in the conflict, a decision that met with very little disappointment in EU circles. ${ }^{145}$ The large contribution of member states to UNIFIL still allowed the EU to play a significant leadership role in the operation.

However, it is not at all clear that the EU has graduated from the status of "payer" to the role of "player" in the international arena. The delays in deploying the EU mission to Chad and the Central African Republic have highlighted the weaknesses in the EU's capacity to launch military operations of this nature. ${ }^{146}$ Lack of air transport, helicopters, and medical facilities hampered early efforts to get the mission off the ground. Such developments do not serve to inspire confidence in the ESDP. Ultimately, the required commitments were made by member states. But several nagging questions remain: Why did this take so long? Why were these commitments not organized at the outset of the mission?

142 Council Joint Action 2004/570/CFSP, 12 July 2004.

143 UNSCR 1575, 22 November 2004; see Part II, paragraphs 10 and 11. The resolution was adopted under Chapter VII of the UN Charter.

${ }^{144}$ UN Security Council, SC/9127, "Security Council Authorizes Establishment of 'Multidimensional Presence’ in Chad, Central African Republic,” unanimously adopting resolution 1778 (2007), 25 September 2007.

145 Personal interview with an Irish EU official, Brussels, September 2007.

146 See Jamie Smyth, "EU Mission to Chad Faces Further Delays,” The Irish Times (29 November 2007); and “Military Approves Chad Mission,” BBC News (11 January 2008). 


\section{Conclusions}

Since 2003, the EU has undertaken a wide range of civilian and military crisis management functions, including the promotion of the rule of law, border control, training of police and security forces, monitoring peace agreements, peacekeeping, and assistance in tackling organized crime. ${ }^{147}$ In this way, the policy adopted can be described as incremental or gradualist in nature, while the operations themselves have been modest in scope. These advances in the CFSP/ESDP clearly demonstrate the ability and willingness of the EU to deploy both civilian and military missions. The EU can no longer be just considered a civilian power, since it has begun the process to develop a military component through the ESDP. ${ }^{148}$ The arrangements under the Berlin Plus structure-whereby the EU is guaranteed access to NATO assets for military operations-have been a significant factor in the development of the ESDP. However, the ESDP should not be equated with the militarization of Europe. It is a policy akin to risk management on a regional basis, ${ }^{149}$ and is focused on building capabilities to back up political compromises in crisis management situations. ${ }^{150}$ In the context of the European Security Strategy and the provision of support for regional organizations, the EU has provided financial planning, political support, and military advice to enable the African Union to launch a peacekeeping mission in Sudan (AMIS II).

The EU has demonstrated its commitment to the UN, although this probably has as much to do with the EU's ambition to play the role of "global actor" as it does with actual European support for the UN itself. The relationship between the EU and the UN is conducted on a higher level than the UN's relationships with other regional organizations, even though the EU does not consider itself a regional organization within the meaning of Chapter VIII of the UN Charter. The increase in the EU's membership to twenty-seven states has enhanced the Union's influence and voting power within the UN without undermining coordination between the two bodies.

The EU can assist UN peacekeeping efforts while strengthening its own visibility. Nonetheless, the EU cannot respond to all the crises and conflicts that occur. It must be selective and prioritize situations according to transparent criteria. Each case is complex, and raises a thorny set of questions. Why Chad and not Darfur? Was the opposition of the Khartoum regime the decisive factor? An informed debate is needed on these issues and, whatever the outcome, criteria should be adopted for how missions will be selected. Likewise, it is clearly in Europe's interest to be involved in Kosovo. A

147 See the Council of the EU, ESPD Newsletter, No. 5 (December 2007), and details on the ESDP at www.consilium.europa.eu/cms3_fo/showPage.asp?id=261\&lang=en.

${ }^{148}$ Ana E. Juncos, “The EU's Post-conflict Intervention in Bosnia and Herzegovina: (re)Integrating the Balkans and/or (re)Inventing the EU?” Southeast European Politics 6:2 (2005): 96.

149 Jolyon Howorth, Security and Defense Policy in the European Union (New York: Palgrave Macmillan, 2007), 10.

${ }^{150}$ Rainer Schuwirth, “Actors and Witnesses,” in EU Security and Defence Policy: The First Five Years (1999-2004), ed. Nicole Gnesotto (Paris: Institute for Security Studies, 2004), 241. 
similar argument can be made with respect to the Middle East, but what of conflict regions such as Aceh, Indonesia and beyond? The EU is willing to listen to demands, but it is likely to insist on political autonomy and an EU chain of command, with the political and strategic control being exercised by the EU Political and Security Committee. ${ }^{151}$ Furthermore, the EU will always be dependent on national decisions to provide troops. Engaging national parliaments in the intergovernmental process is important for democracy and civilian oversight. It also has the advantage of making policy failures more acceptable when they are based on a collective and inclusive process. Ultimately, current ESDP military operations are based on extension of the spirit of a coalition of the willing to permanent structured cooperation. If some EU states are willing to participate in such missions, then those that are unwilling or unable to participate should not impede this commitment.

The UN remains concerned that EU crisis management policy might be developing at the expense of EU contributions to UN peace operations. ${ }^{152}$ The facts indicate that such fears are not unreasonable. ${ }^{153}$ Given the support it has so publicly voiced for the UN, the EU must ensure that this does not happen. The EU member states' agreement to reinforce the UN peacekeeping force in Lebanon (UNIFIL) in 2006 should go some way to allaying such fears. ${ }^{154}$ The idea that the UN will be however allowed to play a decisive role in EU-led operations is unlikely to be acceptable in Europe, given the role of the EU Political and Security Committee and the increasing coherence of the CFSP.

In the international context, the EU is not competing against its own member states, but rather posits itself as an actor among other actors. ${ }^{155}$ Member states exercise real control over decisions relating to the ESDP, but institutional rivalries within the EU have yet to be resolved. The role of the EU in the management of internal crises and the link with external crisis management operations needs to be explored further. The disconnect between intergovernmental ESDP crisis management and Commission activity in the same field remains a significant weakness in the EU's institutional structures involved in such operations. ${ }^{156}$ In practical terms, these activities can be institutionally divorced from one another. This is especially so with civilian crisis management operations, which can lead to inefficient and fragmented approaches. Nor can any clear distinction be made between the roles of the Community (the Commission)

${ }^{151}$ Jim Cloos, "EU-UN Cooperation on Crisis Management - Putting Effective Multilateralism into Practice,” in The United Nations and the European Union: An Even Stronger Partnership, ed. Wouters, Hoffmeister, and Ruys, 263.

152 Personal interview with DPKO official at the United Nations, New York, June 2007.

153 See Wouters and Ruys, "UN-EU Cooperation in Crisis Management,” 248-55.

${ }^{154}$ Information on UNIFIL is available at www.un.org/Depts/dpko/missions/unifil/.

155 Simon Duke and Hanna Ojanen, "Bridging Internal and External Security: Lessons from the European Security and Defence Policy,” Journal of European Defence Policy 28:5 (December 2006): 477-94; quoted at 493.

${ }^{156}$ Catriona Gourlay, "European Union Procedures and Resources for Crisis Management,” International Peacekeeping 11:3 (2004): 404-21. 
and the member states (the Council) in crisis management on the basis of a division of labor or the length of the operation. ${ }^{157}$ While the High Representative, Javier Solana, and the External Relations Commissioner, Chris Patten, worked well together, this level of cooperation cannot be assumed to exist in the future between different individuals. ${ }^{158}$ One recommendation made was for the appointment of a "double-hatted" foreign minister. ${ }^{159}$ This was provided for in the proposed EU Constitution, and was probably the most important foreign policy proposal.

The Lisbon Treaty strengthens the EU's external identity and capacity for international action. ${ }^{160}$ This will be achieved through the formal creation of a single legal personality for the EU, which will strengthen its negotiating power, making it more effective on the world stage and a more visible partner for third countries and international organizations. The Lisbon Treaty dedicates a special section to the ESDP, renaming it the Common Security and Defense Policy (CSDP). ${ }^{161}$ It also expands the range of tasks that may be undertaken. ${ }^{162}$ The establishment of the offices of the EU President and the EU High Representative for Foreign and Security Policy-along with an EU External Action Service that will provide back-up and support to the High Representative-will also help to improve the formulation and implementation of the CFSP.

Progress in the ESDP should not be measured just in security terms, but in steps toward the creation of an environment in which EU standards of justice and political, economic, and cultural norms can apply. Many obstacles will have to be overcome, especially in the fight against organized crime and the corruption that exists throughout the Balkans in particular. A failure in $\mathrm{BiH}$ would be a serious setback for the future of the ESDP. Perhaps the situation was best summed up by the first High Representative to $\mathrm{BiH}$, Carl Bildt:

It is sometimes said that the success of ESDP should be measured by its achievements in the Balkans. While being too limited a view of the tasks of ESDP-with the ESS a far more ambitious agenda has been set-it is nevertheless true that a policy that is seen as failing here will have a hard time making itself a success elsewhere. $^{163}$

${ }^{157}$ Duke and Ojanen, "Bridging Internal and External Security,” 485.

${ }^{158}$ International Crisis Group, EU Crisis Response Capability Revisited, Europe Report No. 160 (??, 17 January 2005), 7.

159 Ibid., 420.

${ }^{160}$ On 13 December 2007, EU leaders signed the Treaty of Lisbon, thus bringing to an end several years of negotiation about institutional reform. It amends the current EU and EC treaties without replacing them.

${ }^{161}$ Lisbon Treaty, Section 2, Chapter II.

${ }^{162}$ Lisbon Treaty, Article 43(1). The tasks include joint disarmament operations, military advice and assistance tasks, conflict prevention tasks, and post-conflict stabilization.

${ }^{163}$ Carl Bildt, "The First Five Years (1999-2004): Actors and Witnesses," in EU Security and Defence Policy: The First Five Years (1999-2004), ed. Nicole Gnesotto, 142. 
The future stability of Europe is inextricably linked with that of Kosovo and the Balkans. ${ }^{164}$ The outbreak of civil disturbances in March 2004, including ethnic cleansing of Serbs, has added to the uncertainty and tension in the region. In Serbia, the government has reacted negatively to Kosovo's declaration of independence. Montenegro has already separated from its "Solana imposed" union with Serbia. ${ }^{165}$ A reciprocal demand by the Republika Srpska, supported by Serbia, remains a possibility.

The EU is not a single state, and it does not possess "state-like military forces."166 Unlike NATO, it does not yet have a collective mutual defense commitment, as its neutral countries have not displayed any willingness to enter into such an arrangement, and there is no such obligation contained in the Treaty on European Union. ${ }^{167}$ The proposed EU Constitution contained a mutual assistance clause, although it stopped short of a commitment to act militarily in a situation where a member state was threatened; instead, it called for member states to recognize the primacy of the UN and international law before undertaking any such activity. ${ }^{168}$ It acknowledged that NATO remains the foundation of the collective defense of those EU states that are also members of that organization. It also drew attention to the contradictions between the EU consensus approach to security and the pre-emptive doctrine of NATO.

For some critics, the ESDP will remain merely an intergovernmental exercise, constrained by national domestic political issues, subject to variable perceptions of national and international interests, and subservient to certain states' commitments to NATO. ${ }^{169}$ Nevertheless, even though the ESDP has been placed under the Second Pillar of the EU (Common Foreign and Security Policy, or CFSP), and as such is not legally binding on the member states, the policy is not merely aspirational. It is now fully operational, and significant advances have been achieved at the planning and opera-

${ }^{164}$ See International Crisis Group, “Kosovo’s Fragile Transition,” Europe Report N¹96 (25 September 2008), and generally the recommendations put forward by the UN Special Envoy Martti Ahtisaari; and Stanley Kobar, “Europe's Approaching Train Wreck,” International Herald Tribune (22 March 2007). See also International Crisis Group, "Kosovo: No Good Alternatives to the Ahtisaari Plan,” Europe Report N¹82 (14 May 2007); and International Crisis Group Media Brief, “Serbia’s New Government: Turning from Europe,” Belgrade/Brussels (31 May 2007).

165 Solana brokered the Belgrade Agreement of 14 March 2002 that dissolved Tito’s Yugoslavia and created the Union of Serbia and Montenegro. This policy was opposed by a majority of Montenegrins, who wanted to be independent of a maligned and impoverished Serbia. See Rory Keane, “The Solana Process in Serbia and Montenegro: Coherence in EU Foreign Policy,” International Peacekeeping 11:3 (2004): 491-507.

${ }^{166}$ Dinan, Ever Closer Union, 605.

${ }^{167}$ Frederik Naert, “European Security and Defence in the EU Constitutional Treaty,” Journal of Conflict and Security Law (2005): 192.

168 Article I-41(7) states that in cases where "a Member State is the victim of armed aggression on its territory, the other Member states shall have towards it an obligation of aid and assistance by all means in their power in accordance with Article 51 of the United Nations Charter."

169 Sloan, NATO, The European Union, and The Atlantic Community, 207. 
tional levels. One of the concerns that perhaps has not fully been analyzed and examined in the literature on EU military operations is that the forces earmarked for deployment are the same troops that are committed to NATO. There is no reservoir of similar forces beyond those units, and these countries do not appear to be in a position to meet any simultaneous requirements that might arise.

The CFSP complements the already strong economic and diplomatic instruments of the EU and its member states. ${ }^{170}$ However, all ESDP missions will inevitably confront human rights issues, yet the development of human rights policy within the ESDP is comparatively immature. ${ }^{171}$ The EU's situation assessments of cases where civil and/or military intervention is envisaged should include a human rights analysis of the region, and the mandate should include human rights protection and promotion as key objectives of achieving lasting peace. In addition, human rights and democracy clauses should, normatively speaking, be included in all EU agreements with third countries so as to contribute to the defense of democracy and basic freedoms throughout the world. ${ }^{172}$ An important lesson that has been learned from the EU operations to date is that military intervention is usually followed by a sustained period of political, economic, and social instability, the resolution of which demands a complex mix of military, diplomatic, humanitarian, and economic approaches and a long-term commitment. ${ }^{173}$

Since the adoption of the European Security Strategy in 2003, the EU has gained considerable experience in managing peace-enforcement, peacekeeping, policing, and civilian operations. The question remains, however, as to whether this indicates that the Union is capable of developing a fully autonomous and coherent military doctrine that will allow EU forces to launch ESDP operations. ${ }^{174}$ It is important to place conditions on the use of military power that include democratic control, accountability, and the "last resort" argument, which stipulates that the use of force is legitimate only in exceptional cases. ${ }^{175}$ The EU must ensure that the use of any military force has international legitimacy, by way of a UN mandate and a broad international consensus. To date, all ESDP missions with a military component have been based on a UN mandate, and thus far international public opinion has been supportive; if anything public opinion has been critical of the EU's failure to deploy forces soon enough to prevent or resolve crisis situations. The EU operations in Macedonia, the Congo, and Bosnia may not be particularly impressive in military terms, but they were accepted by the local

${ }^{170}$ Shepherd, "The European Union's Security and Defence Policy: A Policy without Substance?”, 39.

${ }^{171}$ Jana Arloth and Frauke Seidensticker, The ESDF Crisis Management Operations of the European Union and Human Rights (Berlin: Deutsches Institut fur Menschenrechte, 2007), 53.

${ }^{172}$ Winn, “CFSP, ESDP, and the Future of European Security,” 152.

${ }^{173}$ Ellner, “The European Security Strategy: Multilateral Security with Teeth?”, 224.

${ }^{174}$ Bono, “The EU's Military Doctrine: An Assessment," 453.

175 Juncos, "The EU's Post-conflict Intervention in Bosnia and Herzegovina," 97. 
population in their respective regions. ${ }^{176}$ This may be in large part due to the deployment of civil tools to complement the military objectives, especially in the areas of rule of law and economic development.

The EU has developed an unprecedented mix of civilian and military instruments that should ensure that it will remain a distinctive actor on the world stage in the future. It also has the capacity to support the UN Peacebuilding Commission in post-conflict situations. The challenge for the future for the CFSP/ESDP in the EU lies in bringing together such a disparate group of states to develop a strategic approach that can be agreed on by all members. This should not be exclusively directed towards improving military capabilities, but should continue to retain the fundamental ethos of the EU as a civilian power committed to the principles of the UN and multilateralism in addressing security issues.

${ }^{176}$ Frédéric Charillon, “The EU as a Security Regime,” European Foreign Affairs Review 10:4 (2005): 525. 


\section{THE QUARTERLY JOURNAL}

\section{Bibliography}

A More Secure World: Our Shared Responsibility. Report of the High-level Panel on Threats, Challenges and Change. United Nations, 2004.

A Secure Europe in a Better World - European Security Strategy (ESS). Brussels: European Council, 2003.

Alford, Duncan E.. "European Union Legal Materials: A Guide for the Infrequent Users." Law Library Journal 97, no. 1 (2005): 49-76.

Annual Review of Global Peacekeeping Operations 2007. Boulder: CO: Lynne Rienner, 2007.

Arloth, Jana, and Frauke Seidensticker. The ESDF Crisis Management Operations of the European Union and Human Rights. Berlin: Deutsches Institut fur Menschenrechte, 2007.

Bilefsky, Dan, and Brian Knowlton. "U.S. Reaches out to a Europe that Has Yet to Emerge." International Herald Tribune (2007).

Biscop, Sven, and Edith Drieskens. "The European Security Strategy: Confirming the Choice for Collective and Comprehensive Security." In The United Nations and the European Union: An Even Stronger Partnership, 267. The Hague: TMC Asser Press, 2006.

Biscop, Sven. For a 'More Active' EU in the Middle East In Egmont Paper. Brussels: Royal Institute of International Relations, 2007.

Bono, Giovanna. "The EU's Military Doctrine: An Assessment." International Peacekeeping 11, no. 3 (2004): 444.

Charillon, Frédéric. "The EU as a Security Regime." European Foreign Affairs Review 10, no. 4 (2005): 525.

Cloos, Jim. "EU-UN Cooperation on Crisis Management - Putting Effective Multilateralism into Practice." In The United Nations and the European Union: An Even Stronger Partnership, 263., 2007.

Dannreuther, Roland. European Union Foreign and Security Policy, Towards a Neighbourhood Strategy. Setting the Framework. New York: Routledge, 2005.

Dinan, Desmond. Ever Closer Union: An Introduction to European Integration. 3rd ed. New York: Palgrave Macmillan, 2005.

Duke, Simon, and Hanna Ojanen. "Bridging Internal and External Security: Lessons from the European Security and Defence Policy." Journal of European Defence Policy 28, no. 5 (2006): 477-94; quoted at 493. 
edivý, Jirí Š.. One Year On: Lessons from Iraq In Chaillot Paper. Paris: Institute for Security Studies, 2004.

Ellner, Andrea. "The European Security Strategy: Multilateral Security with Teeth?" Defence and Security Analysis 21 (2005): 226.

ESPD Newsletter. The Council of the EU, 2008.

EU Crisis Response Capability Revisited In Europe Report. International Crisis Group, 2005 .

EU Security and Defence, Core documents 2004 In ESDP Presidency Report. Paris: Institute for Security Studies, 2005.

European Security Strategy, Bosnia and Herzegovina-Comprehensive Policy. European Council, 2004.

Gourlay, Catriona. "European Union Procedures and Resources for Crisis Management." International Peacekeeping 11, no. 3 (2004): 404-21.

Harris, Megan. "Kosovo’s Uncertain Outlook." United Press International (2007).

Howorth, Jolyon. Security and Defense Policy in the European Union. New York: Palgrave Macmillan, 2007.

Juncos, Ana E.. "The EU's Post-conflict Intervention in Bosnia and Herzegovina: (re)Integrating the Balkans and/or (re)Inventing the EU?" Southeast European Politics 6, no. 2 (2005): 96.

Kosovo: No Good Alternatives to the Ahtisaari Plan In Executive Summary and Recommendations in International Crisis Group., 2007.

le Ulriksen, Stå, Catriona Gourlay, and Catriona Mace. "Operation Artemis: The Shape of Things to Come?" International Peacekeeping 11, no. 3 (2004): 513.

le Ulriksen, Stå. "Requirements for Future European Military Strategies and Force Structures." International Peacekeeping 11, no. 3 (2004): 457.

Lindström, Gustav. "On the Ground: ESDP Operations." In EU Security and Defence Policies: The First Five Years (1999-2004), 111. Paris: EU Institute for Security Studies, 2004.

Mace, Catriona. "Operation Concordia: Developing a 'European' Approach to Crisis Management." International Peacekeeping 11, no. 3 (2004): 47.

Meyer, Christoph O.. The Quest for a European Strategic Culture: Changing Norms on Security and Defense in the European Union. New York, NY: Palgrave Macmillan, 2007. 


\section{THE QUARTERLY JOURNAL}

Naert, Frederik. "European Security and Defence in the EU Constitutional Treaty." Journal of Conflict and Security Law (2005): 192.

Official Journal of the European Communities., 1992.

Ortega, Martin. "Beyond Petersberg: Missions for the EU Military Forces." In EU Security and Defence Policy: The First Five Years (1999-2004), 82. Paris: EU Institute for Security Studies, 2004.

Osland, Kari M.. "The EU Police Mission in Bosnia and Herzegovina." International Peacekeeping 11, no. 3 (2004): 544.

Patten, Christopher. The Western Balkans: The Road to Europe In speech to the European Af-fairs Committee in Berlin., 2004.

Presidency Progress Report to the Helsinki European Council on Strengthening the Common European Policy on Security and Defence., 1999.

Quille, Gerrard. "Implementing the Defence Aspects of the European Security Strategy: The Headline Goal 2010." European Security Review 23 (2004): 5.

Quille, Gerrard. "The European Security Strategy: A Framework for EU Security Interests." International Peacekeeping 11, no. 3 (2004): 424.

Ruys, Tom. Background Paper on EU Crisis Management Operations In Working Paper. Leuven: Institute of International Law, Katholieke Universiteit Leuven, 2007.

Salmon, Trevor. "The European Security and Defence Policy: Built on Rocks or Sand?" European Foreign Affairs Review 10, no. 3 (2005): 359.

Schmitt, Burkard. "European Capabilities: How Many Divisions?" In EU Security and Defence Policy: The First Five Years (1999-2004), 89. Paris: EU Institute for Security Studies, 2004.

Schneckener, Ulrich. Developing and Applying EU Crisis Management: Test Case Macedonia In Working Paper. European Centre for Minority Issues, 2002.

Schuwirth, Rainer. "Actors and Witnesses." In EU Security and Defence Policy: The First Five Years (1999-2004), 241. Paris: Institute for Security Studies, 2004.

Serbia's New Government: Turning from Europe In International Crisis Group Media Brief. Belgrade/Brussels, 2007.

Shepherd, Alistair J. K.. "The European Union's Security and Defence Policy: A Policy without Substance?" European Security 12, no. 1 (2003): 40.

Sloan, Stanley R.. NATO, The European Union, and The Atlantic Community, The Transatlantic Bargain Challenged. 2nd ed. New York, NY: Rowan \& Littlefield, 2005. 
Solana, Javier. EU Statement on the Summary of the Report by EUHR for CFSP on a Possible EU deployment in BiH., 2004.

Solana, Javier. The European Strategy - The Next Step In Chaillot Paper. Paris: Institute for Security Studies, 2004.

Stamey, Victor E.. The Way Ahead., 2000.

Tardy, Thierry. EU-UN Cooperation in Peacekeeping: A Promising Relationship in a Constrained Environment. Paris: Institute for Security Studies, 2005.

Terzi, Özlem. "New Capabilities, Old Relationships: Emergent ESDP and EU-Turkish Relations." Southeast European Polities 3 (2002): 43.

The EU Battle Groups and the EU Civilian and Military Cell. EU Factsheet, 2005.

Thym, Daniel. "Beyond Parliament's Reach? The Role of the European Parliament in the CFSP." European Foreign Affairs Review 11, no. 1 (2006): 113.

Toje, Asle. "The 2003 European Union Security Strategy: A Critical Appraisal." European Foreign Affairs Review 10, no. 1 (2005): 129.

Treacher, Adrian. "From Civilian Power to Military Actor: The EU's Resistible Transformation." European Foreign Affairs Review 9 (2004): 56.

Walker, Neil. Europe at 50 - A Midlife Crisis? In Faculty of Law Annual Distinguished Lecture 2007. Galway: National University of Ireland, 2007.

Winn, Neil. "CFSP, ESDP, and the Future of European Security: Whither NATO?" The Brown Journal of World Affairs 9, no. 2 (2003): 149.

Wouters, Jan, and Tom Ruys. "UN-EU Cooperation in Crisis Management." In The United Nations and the European Union: An Even Stronger Partnership, 229-65; quoted at 235. The Hague: TMC Asser Press, 2006.

Wouters, Jan, Frank Hoffmeister, and Tom Ruys. "Introduction." In The United Nations and the European Union: An Even Stronger Partnership, 1. The Hague: TMC Asser Pres, 2006.

Wouters, Jan. The United Nations and the European Union: Partners in Multilateralism In Working Paper. Leuven: Leuven Centre for Global Governance Studies, 2007.

Youngs, Richard. "The European Security and Defence Policy: What Impact on the EU's Approach to Security Challenges?" European Security 11, no. 2 (2002): 101. 